\title{
Foreign Direct Investments and Economic Development and Growth in Nigeria
}

\section{Godly Otto}

\author{
Department of Economics Faculty of Social Sciences
} University of Port Harcourt godlyotto@yahoo.com

\section{Wilfred I Ukpere}

\author{
Department of Industrial Psychology \& People Management, \\ Faculty of Management, University of Johannesburg, South Africa \\ Correspondence author's E-mail: wilfredisiomaukpere@gmail.com
}

\section{Doi:10.5901/mjss.2014.v5n2p713}

Abstract

Developing economies are characterized by high rates of poverty, unemployment, inadequate capital, low or obsolete technology, and information gaps amongst many others. To mitigate these problems, many developing countries seek foreign direct investments. This is because such investments are believed to facilitate capital inflow, technology transfer, information flows into the host economies and thereby increase total output. Some developing countries exemplify these benefits. However, experience in many developing countries show that these expectations have not been met. In some of these countries, foreign direct investments as multinational companies have actually undermined host economies. This work examined the praxis in Nigeria over a - 41 - year period and observed that there is a positive relationship between Foreign direct investments and economic growth in Nigeria. Policies are required which will facilitate foreign direct investments into Nigerian economy especially in the non-oil sector.

Keywords: Foreign Direct Investments, Economic Growth, Exchange Rate

\section{Background}

Nigeria is blessed with abundance of natural and human resources. It is estimated that the country (which is commonly referred to as Giant of Africa) has about 61 mineral resources, each of which has the capacity to sustain the economy (Ejeogu, 2011). Unfortunately, these resources are largely lying latent and the economy is mono-culturally dependent on petroleum for its survival. Over 90 per cent of Nigeria's foreign receipts are accounted for by oil and because of volatility of oil prices, the economy suffers when there is a glut in the international oil market (Devlin and Titman 2004). Besides, because there is a tenuos nexus between the oil sector and the rest of the local economy, unemployment is high, poverty is prevalence and security is a current challenge (Okonjo-Iweala 2012, Olugbile 2012). A key reason for this situation is inadequate capital and technical knowhow necessary to tap from the abundant unemployed resources (Roberts and Tybout 1997). The need for technological advancement is imperative in Nigeria.

The country is in dire need to expand its output, improve its resource use (employment), enhance social welfare and limit its overdependence on oil exports (Adetayo, 2012). This has informed the search for strategies that will generate economic growth. One such strategy is the Foreign Direct Investments. Foreign direct investments (FDI) are believed to be key source of productivity expansion because they have capacity for technology transfer. FDI can also increase access to foreign markets and in concert with local resources can increase competitiveness of products because of cheap labour in host countries. In point, Foreign direct investments could generate economic growth in host Countries. However, how well has this been done in Nigeria? This article investigates the relationship between Foreign Direct Investments and Economic Growth in Nigeria.

\section{Conceptual Framework}

According to Todaro and Smith (2003), foreign direct investments (FDI) define overseas investments by private multinational corporations. In other words, foreign direct Investments are multinational investments overseas. This link 
is important to clearly see the conceptual relationship between multinational corporations and foreign direct investments. It is generally accepted that a multinational or transnational enterprise is an enterprise that engage in foreign direct investments in more than one country. The above definition is generally accepted in academic and business circles including data collecting agencies such as the Organization for Economic Co-operation and Development (OECD), The United Nations Centre for Transnational Corporations (UNCTC) and by many national governments (Otto 2004). Summarily, a foreign direct investment is an international business activity. But unlike an indirect investment, the investor is physically present in the host country or through his staff and is actually engaged in direct productive activities in more than one country. The investor has a direct control over his investment resources in the host and home countries. In point, foreign direct investments are private international business outfits in which the investors have direct control over their operations and their capital resources. Examples of foreign direct investments are common in Nigeria. They include A.G. Leventis and Companies, Exxon Mobil Producing Unlimited, Michelin, MTN, Total, Elf Oil among many others.

According to the Financial Standard of May 26, 2008, Nigeria attracted 12.5billion dollars worth of foreign investments in 2007 alone and that the Nation had a significant rise in the volume of foreign direct investments from one billion dollars in 1999 to 12.5 billion dollars in 2007. This information is reinforced by the Vanguard of May 26, 2008. According to the Vanguard, Nigeria attracts 29.4 per cent of total foreign direct investment resources meant for Africa, South Africa attracts 18.2 per cent while Equatorial Guinea attracts about 10 per cent. But where are those investments and how do they impact on the Nigerian economy. These questions become more worrisome when juxtaposed against the high level of unemployment in the country.

Much of the foreign direct Investments in developing countries are from the Advanced economies of Europe and North America, though the influence of emerging developing countries as China, the Asian Tigers and Brazil is acknowledged. According to the International Monetary Fund (IMF) Year Book (1992) 15 countries account for 70.4\% of the World's total foreign direct investments and the leading three of these are the United States, Canada and the United Kingdom. Foreign Direct Investments flow to both developing and developed countries. An American investor could invest in Britain, Germany, Japan, Nigeria or Ghana depending on his interests and what the receiving country offers. This work attempts to examine the impact of foreign direct investment in Nigeria.

\section{Motive of Investors}

The main motive of foreign direct investments are perceived to be the advancement of long term business profitability which is made up of two components; profitability of the foreign affiliate and the effect of the foreign activity on the total stock of investment outlay. This can be mathematically presented as follows

$$
\begin{aligned}
& \sum \pi=\frac{A R-A C}{K}=\frac{\left(T R_{h}-T C_{h}\right)}{K}+\frac{T R_{f}-T C_{f}}{K} \ldots \ldots \ldots \ldots \ldots \ldots \ldots \ldots \ldots \ldots \\
& \sum \pi_{i f}=\pi_{h}+\pi_{i f}+\pi_{f 2}+\pi_{f 3}+\ldots \pi_{f n} \ldots \ldots \ldots \ldots \ldots \ldots
\end{aligned}
$$

Where:

$\sum \pi$ defines total profits

$\mathrm{TR}_{\mathrm{h}}$ defines Total Revenue of the home investments

$T R f$ defines Total Revenue from foreign investments

$\Pi_{\mathrm{f} 1}$ - $\mathrm{n}$ defines profits in different host countries

$\mathrm{TC}$ defines total cost of home investment activities

$\mathrm{TC}_{\mathrm{f}}$ defines total cost of foreign investments activities

$A R=$ Average revenue on investment activities

$A C=$ Average cost of investment activities

$\mathrm{K}=$ owners capital

At least, four types of foreign investors have been noted over the years. These are generally classified into
(a) Resource seekers
(b) Market seekers
(c) Efficiency seekers
(d) Strategic asset or capability seekers 
There are other reasons for investments which appear less preponderant but which do not neatly fit into the classification above. These include escape investments, support investments and passive investments. Passive investments are based on speculation that these investments may turn out profitable in the future. Escape investments are done to escape restrictive laws or macroeconomic policies by host governments. For instance, the establishment of farms by UAC (United African Company) in Nigeria in the 1980s was on escape investment of the Buhari-Idiagbon Administration. Support investments are more of auxiliaries to the main investments and may be done as parts of vertical integration.

There has been so much debate on the role or impact of Foreign Direct Investments on the economy of host countries especially developing economies. The polemics polarize into two: those for and those against. Protagonists believe the benefits of FDI include foreign capital in-flows, exchange of skills (i.e. technology transfer) and information. Other benefits include expertise, job opportunities and improved productivity. Some developing countries exemplify the possibilities of these benefits. For instance, the Asian tigers benefited massively from foreign direct investments and experienced a high level of economic growth for many years. According to http//www.economywatch.com/fdi culled on 29/4/2012, foreign direct investments to developing countries rose from on average of $\$ 2.4$ billion in 1962 to $\$ 11$ billion in 1980 to $\$ 35$ billion in 1986, $\$ 85$ billion in 1990, $\$ 481$ billion in 1998 and to $\$ 636$ billion in 2006. China had been at the fore front of recipient economies, followed by Russia, Brazil and Mexico. As at 2011, China had $\$ 116$ billion worth of foreign direct investments which was expected to rise to $\$ 123$ billion in 2012. in fact, in April 2012, Ford Motors announced it was going to invest another 600 million dollars in China. (See http://www.economywatch.com/fulsculled on 29/9/12)

In turn, the Chinese economy has grown from a small developing economy to the second largest economy in the world, and an emerging exporter of capital and foreign direct investments.

Table 1 presents in percentage form recipients of foreign direct investments among developing countries between 1970 1999.

Table 1: Foreign Direct Inflow to Developing Countries(1970-1999)

\begin{tabular}{|l|l|c|c|}
\hline $\mathbf{s} / \mathbf{n}$ & Recipient & FDI Received \% for all LDCs & $\begin{array}{c}\text { Current(2012) } \\
\text { Population }\end{array}$ \\
\hline 1 & China & 21 & $1,347,350,000$ \\
\hline 2 & Brazil & 18 & $193,946,886$ \\
\hline 3 & Argentina & 13 & $40,117,096$ \\
\hline 4 & Mexico & 6 & $112,336,538$ \\
\hline 5 & South Korea & 5 & $56,004,441$ \\
\hline 6 & Chile & 5 & $16,572,475$ \\
\hline 7 & Poland & 4 & $38,538,447$ \\
\hline 8 & Thailand & 3 & $65,926,261$ \\
\hline 9 & All other LDC & 25 & \\
\hline
\end{tabular}

Source:Todaro and Smith (2003),http//en.wikipidea.org/listofcountriesbyp.c. culled on 1/1/13.

This means that over 70 per cent of foreign investments to the middle and low income countries were accounted for by only 7 countries. According to Todaro and Smith (2003), about 60 per cent of these resources went to Asia. Africa only got about 3 per cent and the least developing countries had less than 2 per cent. This according to Todaro and Smith (2003) is because such investments being private investments gravitate towards countries and regions with the highest financial returns and the greatest perceived safety. According to Tamuno and Otto (2006:71) an advantage of foreign direct investment is that it is less volatile, at least when compared to bank lending and other short term instruments. So it could help boost productivity in an economy. But opponents of foreign direct investments see it as an index of foreign ownership of domestic productive assets such as factories, lands, organization among others. They see foreign direct investments as major drivers of globalization which accounts for over half of all international (cross-border) investments with a profound effect in the developing countries. And the fear is that FDI compete with local industries, erode local capability and keep economies weaker or subjugated. For some scholars, it has become a tool of colonialism (neocolonialism of some sort). Local senior officials of foreign investments are seen as comprador bourgeosie who exploit their kiths and kins for the benefits of the bourgeosie in the metropole. This view is quite common among political economists as Samir Amin, Paul Baran, Paul Sweezy, Walter Rodney among others. 
In fact, according to Baran and Sweezy (1966), the internationalization of firms is an inevitable outcome of the capitalist system and is a means of increasing the monopoly power of the investing firm or country. According to Todaro and Smith (2003), FDI are largely unconcerned about poverty, inequality and unemployment but their focus is on the best profitable opportunities, and this explains why 91 per cent of global investments are located in industrial economies and fast growing developing economies. In many African economies, the pattern of foreign direct investments reinforced the complementarity between those economies, and the structural dependence of the developing economies on the advanced capitalist economies(Ake, 1981). According to Onimode (1983), evidence in many developing countries show that foreign direct investments are engaged in labour exploitation, intensive de-capitalization, create technological backwardness structural distortions, cultural degradation, and persistent underdevelopment among other abuses. Some of these abuses could be tackled through trade policies. According to Harrison et al., (2004) Brazil was able to experience between 1.5 - 5.5 per cent gains especially among the poor through optimal trade policies.

Summarily, the extant views about foreign direct investments polarize. While many scholars see foreign direct investments as beneficial and extremely desirable especially in developing countries where capital inadequacies for investment is the norm rather than the exception, there are other scholars who claim that these investments compete with local investors and crowd out local entrepreneurs from the investing space and as such weaken the local economy instead of building it. This work attempts to find the praxis by examining the impact of foreign direct investments on economic growth in Nigeria.

\section{Methodology}

This work adopts time series analysis; the study examined the impact of foreign direct investments on the Gross Domestic Product (GDP) of Nigeria including exchange rate as a check variable. The mathematical model may be stated as:

$$
G D P=a+a_{1} F D I+a_{\|} E X R
$$

Equation (3) may be cast in Econometric terms as

$$
\mathrm{GDP}=\mathrm{a}_{0}+\mathrm{a}_{1} \mathrm{FDI}+\mathrm{a}_{\|} \mathrm{EXR}+\mathrm{u} \text {. }
$$

Where: $\quad u$ defines the Stochastic elements

$\mathrm{FDI}=$ Foreign Direct Investments

$$
\text { GDP = Gross Domestic Product (proxy for economic growth) }
$$

EXR = Exchange Rate

$$
\begin{aligned}
& a=\text { the Intercept } \\
& a_{\text {I- }} a_{\|}=\text {coefficients }
\end{aligned}
$$

Table 2: Annual Gross Domestic Product and Foreign Direct Investment 1970 - 2010

\begin{tabular}{|c|c|c|}
\hline Year & RGDP NM & FDI NM \\
\hline 1970 & 4219 & 128.6 \\
\hline 1971 & 4715.5 & 142.8 \\
\hline 1972 & 4892.8 & 297.8 \\
\hline 1973 & 5310 & 186.3 \\
\hline 1974 & 15919.7 & 181.6 \\
\hline 1975 & 37172 & 253 \\
\hline 1976 & 29146.5 & 212.5 \\
\hline 1977 & 31520.3 & 245.5 \\
\hline 1978 & 29212.4 & 134.4 \\
\hline 1979 & 29948 & 184.3 \\
\hline 1980 & 31546.8 & -404.1 \\
\hline 1981 & 205222.1 & 334.7 \\
\hline 1982 & 199685.3 & 290 \\
\hline 1983 & 185598.1 & 264.3 \\
\hline 1984 & 183563 & 360.4 \\
\hline 1985 & 201036.3 & 434.1 \\
\hline 1986 & 205971.4 & 735.8 \\
\hline
\end{tabular}




\begin{tabular}{|c|c|c|}
\hline 1987 & 204806.5 & 2452.8 \\
\hline 1988 & 219875.6 & 1718.2 \\
\hline 1989 & 236729.6 & 13877.4 \\
\hline 1990 & 267550 & 4666 \\
\hline 1991 & 2635279.1 & 6916.1 \\
\hline 1992 & 271565.5 & 14463.1 \\
\hline 1993 & 274833.3 & 29675.2 \\
\hline 1994 & 275450.6 & 22229.2 \\
\hline 1995 & 281407.4 & 75940.6 \\
\hline 1996 & 293745.4 & 111295 \\
\hline 1997 & 302022.5 & 110452.7 \\
\hline 1998 & 310890.1 & 80750.4 \\
\hline 1999 & 312183.5 & 92792.5 \\
\hline 2000 & 329178.7 & 115952.2 \\
\hline 2001 & 356694.3 & 132481 \\
\hline 2002 & 433203.5 & 225224.8 \\
\hline 2003 & 477533 & 258388.6 \\
\hline 2004 & 527576 & 248224.6 \\
\hline 2005 & 561931.4 & 654193.1 \\
\hline 2006 & 595821.6 & 1779595 \\
\hline 2007 & 634251.1 & 759380.4 \\
\hline 2008 & 672202.6 & 803675.7 \\
\hline 2009 & 716949.7 & 7284945 \\
\hline 2010 & 694576.2 & 2656649 \\
\hline
\end{tabular}

Source: CBN Statistical Bulletin

Table 2: The Research Data

\begin{tabular}{|c|c|c|c|}
\hline Year & RGDP NM & FDI NM & EXRN; \$ \\
\hline 1970 & 4219 & 128.6 & 0.7143 \\
\hline 1971 & 4715.5 & 142.8 & 0.6955 \\
\hline 1972 & 4892.8 & 297.8 & 0.6579 \\
\hline 1973 & 5310 & 186.3 & 0.6579 \\
\hline 1974 & 15919.7 & 181.6 & 0.6299 \\
\hline 1975 & 37172 & 253 & 0.6159 \\
\hline 1976 & 29146.5 & 212.5 & 0.6265 \\
\hline 1977 & 31520.3 & 245.5 & 0.6466 \\
\hline 1978 & 29212.4 & 134.4 & 0.6060 \\
\hline 1979 & 29948 & 184.3 & 0.5757 \\
\hline 1980 & 31546.8 & -404.1 & 0.5957 \\
\hline 1981 & 205222.1 & 334.7 & 0.61 \\
\hline 1982 & 199685.3 & 290 & 0.6729 \\
\hline 1983 & 185598.1 & 264.3 & 0.7241 \\
\hline 1984 & 183563 & 360.4 & 0.7649 \\
\hline 1985 & 201036.3 & 434.1 & 0.8938 \\
\hline 1986 & 205971.4 & 735.8 & 2.0206 \\
\hline 1987 & 204806.5 & 2452.8 & 4.0179 \\
\hline 1988 & 219875.6 & 1718.2 & 4.5367 \\
\hline 1989 & 236729.6 & 13877.4 & 7.3916 \\
\hline 1990 & 267550 & 4666 & 8.0378 \\
\hline 1991 & 2635279.1 & 6916.1 & 9.9095 \\
\hline 1992 & 271565.5 & 14463.1 & 17.2984 \\
\hline
\end{tabular}




\begin{tabular}{|c|c|c|c|}
\hline 1993 & 274833.3 & 29675.2 & 22.0511 \\
\hline 1994 & 275450.6 & 22229.2 & 21.8861 \\
\hline 1995 & 281407.4 & 75940.6 & 21.8861 \\
\hline 1996 & 293745.4 & 111295 & 21.8861 \\
\hline 1997 & 302022.5 & 110452.7 & 21.8861 \\
\hline 1998 & 310890.1 & 80750.4 & 21.8861 \\
\hline 1999 & 312183.5 & 92792.5 & 92.6934 \\
\hline 2000 & 329178.7 & 115952.2 & 102.1052 \\
\hline 2001 & 356694.3 & 132481 & 111.9422 \\
\hline 2002 & 433203.5 & 225224.8 & 120.9702 \\
\hline 2003 & 477533 & 258388.6 & 129.3565 \\
\hline 2004 & 527576 & 248224.6 & 133.5004 \\
\hline 2005 & 561931.4 & 654193.1 & 132.147 \\
\hline 2006 & 595821.6 & 1779595 & 128.6316 \\
\hline 2007 & 634251.1 & 759380.4 & 125.8331 \\
\hline 2008 & 672202.6 & 803675.7 & 118.5669 \\
\hline 2009 & 716949.7 & 7284945 & 148.9017 \\
\hline 2010 & 694576.2 & 2656649 & 148.31 \\
\hline
\end{tabular}

\section{Source: Central Bank of Nigeria (CBN) Statistical Bulletin (2010)}

Table 3: The Short - Run Estimated Linear Model

\begin{tabular}{|c|c|c|c|c|}
\hline \multicolumn{5}{|c|}{ Dependent variable RGDP } \\
\hline \multicolumn{5}{|c|}{ Method Least Squares } \\
\hline \multicolumn{5}{|c|}{ Date: 11/10/12 Time:19:02 } \\
\hline \multicolumn{5}{|l|}{ Sample: 19702010} \\
\hline \multicolumn{5}{|c|}{ Included observations: 41} \\
\hline Variable & Coefficient & Std Error & t-Statistic & Prob. \\
\hline & & & & \\
\hline $\mathrm{C}$ & 131445.5 & 18905.61 & 6.952727 & 0.0000 \\
\hline FDI & 0.024915 & 0.014972 & 1.664112 & 0.1043 \\
\hline EXR & 3041.671 & 329.1807 & 9240127 & 0.0000 \\
\hline R-squared & 0.7988749 & Mean dep & & 266125.3 \\
\hline Adjusted R-Square & 0.788156 & S.D. depe & & 209183.2 \\
\hline S.E of regression & 96279.64 & Akaike inf & & 25.85826 \\
\hline Sum squared resid & $3.52 \mathrm{E}+11$ & Schwarz & & 25.98364 \\
\hline Log likelihood & -527.0943 & Hamman- & & 25.90391 \\
\hline F-statistic & 75.40927 & Durbin-W & & 0.412151 \\
\hline Prob (F-statistic) & 0.000000 & & & \\
\hline
\end{tabular}

This work uses a data set that covers forty-one years to assess the impact of Foreign Direct Investment on the Gross Domestic Product in Nigeria. The data were sourced from the Central Bank (2010). See Table 2.

\section{Interpretation of Results}

The result of the model estimation suggests that Foreign Direct Investments and the Exchange rate positively impact on the real Gross Domestic Product in Nigeria. The ordinary least squares regression results of the linear model show that the exchange rate and foreign direct investment can explain $79.88 \%$ of the changes in Gross Domestic Product in Nigeria. There is a direct theoretical relationship between foreign direct investments and Economic growth. As more foreign direct investments flow into an economy, it tends to increase domestic output and exports and ipso facto, strengthen the value of the local currency. This is because as exports of locally produced goods are increased, the 
demand for the local currency rises. Again the flow of foreign currency to the domestic economy increases the supply or availability of such currencies vis-à-vis local currencies. This helps to strengthen the local currency in a flexible exchange regime. In point the flow of foreign direct investments increase the volume of foreign currency in the local economy, expands the ability of the local currency to access foreign inputs and the ability of the host economy to increase output. As stated earlier the data used here are time series data obtained from the Central Bank of Nigeria. So this interpretation must be understood in that context. Moreso, because a stationarity test was not carried out in this work.

It is a known fact that historical data could suffer from serial correlation which could render such results spurious. The Durbin-Watson of 0.412 suggests an error but this also can arise because of the number and type of explanatory variables. For this work, the attention has been the impact of foreign direct investments on the gross domestic product in Nigeria. There are also polemics over the appropriateness of using gross domestic product as proxy for economic growth as used here, but GDP is an appropriate measure for total output of a country. What has been used here is the real GDP. As shown in Table 2, the real Gross Domestic Product seem to show the picture of economic performance in Nigeria within this period. In some years, there were relative drops in total output, which signifies negative growth and in other cases an increase in output which signifies positive growth. The real GDP data is therefore sufficient to define economic growth. Though, the marginal changes may define growth also.

\section{Conclusion}

From the data above, it can be concluded that foreign direct investment is a major determinant of economic growth in Nigeria. This explains why different governments in Nigeria concert efforts to source for foreign investors into the country. This view has informed the drive among many serving political officers to scout for foreign investments from all over the world. In President Obasanjo's first tenure in office (i.e. 1999 - 2003) he traveled to every strong economy and met Presidents with a view to attract foreign investment to Nigeria. The attraction of foreign direct investments to Nigeria has also been a key objective of almost all state governments in Nigeria. As a developing economy, Nigeria is labour abundant and needs capital to combine with land and labour resources to improve its employment and output. This can be enhanced through foreign direct investments. In addition foreign direct investments can increase access to knowledge transfers. In fact, Nigeria is a mono-product economy. This main product is managed by foreign direct investors especially the upstream activities. If foreign investors are encouraged into other sectors, the economy may grow faster. To attract foreign investors to Nigeria, the problem of insecurity, corruption, multiple taxations, the emerging culture of minimum work for maximum pay, a disconnection between output and earnings are real problems that government must minimize through functional policies. These problems look difficult to surmount because some of these have deep roots and are informed by social institutions but perhaps with re-orientation, positive results may be achieved. Historically, foreign direct investments flow to countries with raw material base, high population and markets, domestic excess capacity, political and economic stability, including stable wage policies (Tamuno \& Otto, 2006). These factors enhance planning and encourage profits for the foreign investor which is a major objective of foreign investors but FDI involvement can enhance local economic activity, employment and in the end lead to mutual benefits. Some of the required factors are available locally. Government should encourage the presence of the missing factors. It should act beyond mere rhetoric.

\section{References}

Adetayo, D. (2012). 'Jonathan Promises to End Nigeria's over dependence on oil'. The Punch Newspapers. Wednesday November 28. P.10.

Ake, Claude (1981). A Political Economy of Africa. Longman New York.

Baron, Alfred P., and Paul, Sweezy (1966). Monopoly Capital: An Essay on the American Social Order. Monthly Review Press. New York.1

Devlin, Julia and Sheridan Titman (2004). 'Managing Oil Price Risk in Developing Countries' The World Bank Research Observer. Vol. 19(1) Spring.

Ejeogu, S. (2011) Challenges and Implications of the New Democratic Dispensation for Business and Leadership in Nigeria Unpublished speech at the investiture of Fellows, Institute of Natural Resources and Human Development, Port Harcourt

Harrison, G.W, Rutherford, T.F. Tarr, D.G. and Gorgel A. (2004). 'Trade Policy and Poverty Reduction in Brazil'. The World Bank Economic Review. Vol. 18(3).

International Monetary Fund (1992). Fact book New York

Kozo, H. (2012). 'Asian Currencies Drop on Economic Slow Down'. The Punch. Lagos, Monday July 16 P.53. 
Okonjo-Iweala, N (2012) 'Kidnappers Quized My Mum on Subsidy Payments' The Punch Tuesday, December 18, P12, Vol. 17 (2095) Lagos.

Olugbile, S. (2012) 'Vice-Chancellor Advocates Community Policing to Curb Insecurity' The Punch Tuesday December 18, P47, Vol. 17 (2095) Lagos.

Onimode, B (1983). Imperialism and National Development. Zed Pub Nig

Otto, G (2004). International Business Monograph, unpublished Port Harcourt

Roberts, M.J. and J.R. Tybout (1997). 'Producer Turnover and Productivity Growth in Developing Countries'. The World Bank Research Observer. Vol. 12 (1) Feb.

Tamuno, S. and G. Otto (2006). Project Planning and Evaluation in Nigeria. Springfield Pub. Owerri.

Todaro and S. Smith (2003). Economic Development. Pearson Education $8^{\text {th }}$ ed. India. 